\title{
Sorption of Eu (III) onto Nano-Sized H-Titanates of Different Structures
}

\author{
Vladimir G. Petrov ${ }^{1, *}$, Zhong Chen ${ }^{2}$, Anna Yu. Romanchuk ${ }^{1}$, Valeria O. Demina ${ }^{1}$, \\ Yuxin Tang ${ }^{2}$ and Stepan N. Kalmykov ${ }^{1}$ \\ 1 Department of Chemistry, Lomonosov Moscow State University, Leninskie Gory 1 bld. 3, \\ 119991 Moscow, Russia; romanchuk.anna@gmail.com (A.Y.R.); lera.seredina@yandex.ru (V.O.D.); \\ stepan@radio.chem.msu.ru (S.N.K.) \\ 2 School of Materials Science and Engineering, Nanyang Technological University, 50 Nanyang Avenue, \\ Singapore 639798, Singapore; ASZChen@ntu.edu.sg (Z.C.); YXTang@ntu.edu.sg (Y.T.) \\ * Correspondence: vladimir.g.petrov@gmail.com
}

Received: 8 December 2018; Accepted: 12 February 2019; Published: 18 February 2019

\begin{abstract}
Hydrogen titanates (H-titanates) of different nanostructures (nanotubes, nanowires, nanosheets) have been synthesized by hydrothermal methods. The europium (III) sorption from aqueous solutions onto nano-sized H-titanates was studied as a function of contact time, $\mathrm{pH}$ values, and initial Eu (III) concentration in batch experiments. Reversibility of adsorption of europium has been investigated as well. Nano-sized H-titanates can be used for tri-valent f-elements removal in polluted water treatment due to fast and efficient sorption of Eu (III).
\end{abstract}

Keywords: H-titanates; europium; radionuclides removal; sorption; water treatment

\section{Introduction}

The development of nuclear energy results in increasing discharge of radionuclides in natural environments due to accidents in nuclear power or reprocessing plants [1]. Among different products, actinides and lanthanides are formed in spent nuclear fuel (SNF) and radioactive waste (RW). Thus, storage and reprocessing of SNF and RW can release these elements, as well as other components, into the natural water and soil environment. Transplutonium actinides (mainly, Am and Cm) and lanthanides formed in nuclear fuel during its operation are important hazardous elements due to their high toxicity and radioactivity. Therefore, it is very important to develop materials and methods for their effective removal from wastewater and groundwater.

Americium and curium present only in trivalent form under environmental conditions and their chemical behavior is very close to lanthanides, particularly Eu (III). Different techniques of An (III)/Ln (III) extraction from water solutions have been developed using inorganic sorbents [2-11], organic/polymer sorbents [12-15], and different types of chromatography [16-18]. Recently nanosized $\mathrm{Na}, \mathrm{H}$-titanates attracted attention due to their properties. They have layered crystal structure, high ion exchange capacity, high surface charge, and fast ion diffusivity. Layered nanosized titanates have different structures and morphology [19,20]: Nanotubes, nanowires, nanospherulites, etc. It was demonstrated that these materials can effectively remove heavy metals [21,22], cesium [23], strontium [22], thorium [24], and uranium [25,26] from water solutions. Usually, only one type of nanotitanate structure is studied in a research work. In this work we have investigated the sorption of europium (III), as an analogue of An (III), onto nano-sized H-titanates with different structures. 


\section{Materials and Methods}

The procedure to prepare various titanate nanostructures is described as follows. In all synthesis experiments, anatase $\mathrm{TiO}_{2}$ particles (Sigma-Aldrich, USA) were used as the precursor. The short titanate nanotubes were synthesized following the conventional hydrothermal synthesis method [20,27]. In a typical experiment, $0.5 \mathrm{~g} \mathrm{TiO}_{2}$ particles were dispersed in $80 \mathrm{~mL} 10 \mathrm{M} \mathrm{NaOH}$ solution and transferred into a $125 \mathrm{~mL}$ Teflon-lined stainless-steel autoclave. The hydrothermal synthesis was carried out at $130{ }^{\circ} \mathrm{C}$ for $48 \mathrm{~h}$. The short titanate nanowires were synthesized under the same synthesis conditions and procedure, except that the temperature was set at $170{ }^{\circ} \mathrm{C}$ for $48 \mathrm{~h}$. For the synthesis of titanate nanosheet structures, the $\mathrm{NaOH}$ concentration was lowered to $5 \mathrm{M}$, and the synthesis was carried out at $150{ }^{\circ} \mathrm{C}$ for $48 \mathrm{~h}$.

The long titanate nanotube and nanowire samples were synthesized using a stirring hydrothermal method detailed elsewhere [20,28]. In a typical experiment, $0.1 \mathrm{~g} \mathrm{TiO}_{2}$ particles were dispersed in $15 \mathrm{~mL}$ $10 \mathrm{M} \mathrm{NaOH}$ solution via continuous stirring. The solution with dispersed particles was then transferred into a $23 \mathrm{~mL}$ Teflon-lined stainless-steel autoclave with a magnetic stirrer placed inside. The autoclave was placed in a silicone oil bath heated to a designated synthesis temperature. During the synthesis, magnetic stirring rate was maintained at $500 \mathrm{rpm}$. Long titanate nanotubes were obtained after the stirring hydrothermal synthesis at $130{ }^{\circ} \mathrm{C}$ for $48 \mathrm{~h}$. Long titanate nanowires were synthesized at $170{ }^{\circ} \mathrm{C}$ for $24 \mathrm{~h}$.

After the above syntheses were completed, different forms of sodium titanate precipitates were produced and collected using a centrifuge. The as-synthesized precipitates were washed with DI water several times until the $\mathrm{pH}$ value of the water solution decreased to around 7 . The collected precipitates were then soaked in a $0.6 \mathrm{M} \mathrm{HCl}$ solution for $72 \mathrm{~h}$, under constant stirring, and collected by centrifugation. The sample was then washed by DI water as described above. The entire process of proton exchange was repeated 2-3 times until the $\mathrm{pH}$ of the solution reached around 6, which indicated that the sodium ions were completely exchanged by hydrogen ions to form hydrogen titanate, while the nanostructures of the sodium titanates were retained.

The morphology of synthesized H-titanates was studied by scanning electron microscopy.

Specific surface area of the synthesized $\mathrm{H}$-titanates samples was determined by $\mathrm{N}_{2}$ sorption-desorption and further fitting with the BET (Brunauer-Emmett-Teller) model [29].

The ${ }^{152} \mathrm{Eu}$ radionuclide was used in this study to determine the content of europium in water solutions. All other commercial reagents were of analytical grade and used as received. All solutions were prepared with deionized MilliQ water.

All experiments were carried out at ambient atmospheric conditions and at room temperature $\left(22-23^{\circ} \mathrm{C}\right)$.

Radionuclide removal was studied in aqueous solutions at different $\mathrm{pH}$ values. Solutions were prepared with deionized water and $\mathrm{pH}$ values were adjusted with $0.1 \mathrm{M} \mathrm{NaOH}$ and $0.1 \mathrm{M} \mathrm{HCl}$ solutions after the addition of H-titanates. The solid to liquid ratio was $1 \mathrm{~g} \mathrm{~L}^{-1}$ in all experiments. Europium solutions were prepared by dilution of $\mathrm{Eu}\left(\mathrm{NO}_{3}\right)_{3}$ stock solution (natural content of stable isotopes). ${ }^{152} \mathrm{Eu}\left(\mathrm{T}_{1 / 2}=13.54\right.$ years) was added as tracer to measure europium content by $\gamma$-ray spectrometry (high purity germanium detector, GC 3020, Canberra, Australia). Total initial concentration of europium was ca. $10^{-9} \mathrm{M}$. H-titanates were added first in water solution, then aliquots of Eu stock solution were added, and further $\mathrm{pH}$ values were adjusted. Then solutions were intensively shaken for few seconds and left on the orbital shaker. The solutions at $\mathrm{pH} 4$ were sampled periodically to determine the optimal equilibration time-i.e., time when the steady-state is reached. All other samples were sampled after two days of experimentation, after re-measurement of the $\mathrm{pH}$ values. All samples were centrifuged at $40,000 \times g$ within $10 \mathrm{~min}$ to remove particles of H-titanates. Supernatants were then analyzed for the content of europium. Sorption isotherms were obtained in the same manner, but the initial concentration of $\mathrm{Eu}$ (III) was varied from $10^{-9} \mathrm{M}$ to $10^{-4} \mathrm{M}$. 


\section{Results}

The morphology of synthesized H-titanates revealed by scanning electron microscopy is presented in Figure 1.

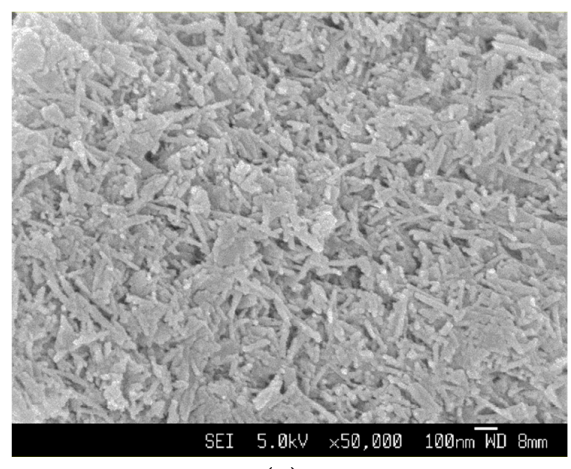

(a)

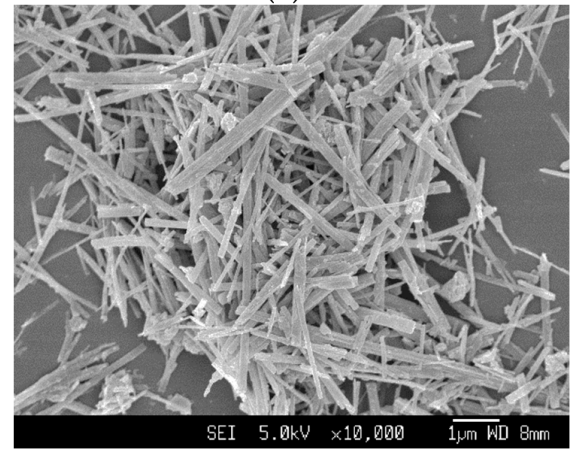

(c)

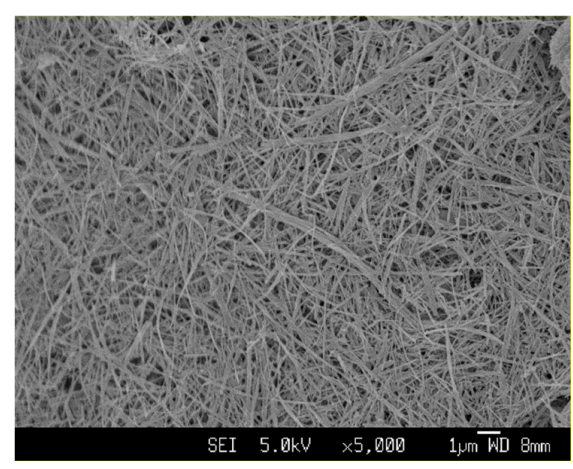

(b)

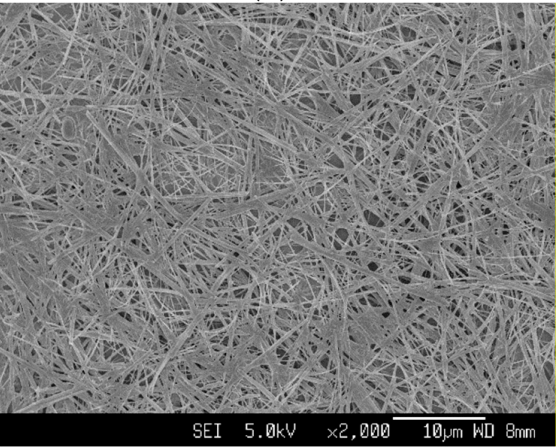

(d)

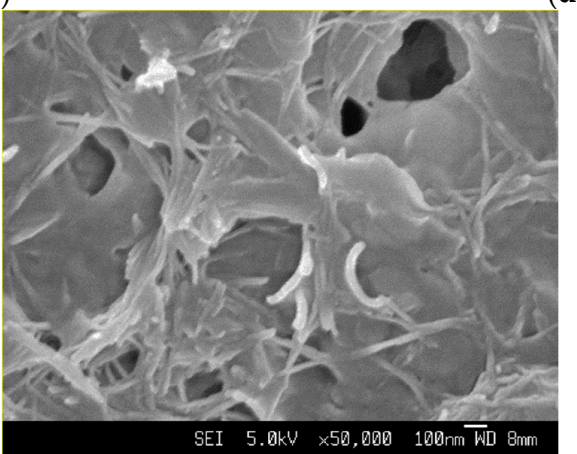

(e)

Figure 1. SEM images of H-titanates of different structures: (a) nanotubes short; (b) nanotubes long; (c) nanowires short; (d) nanowires long; (e) nanosheets.

Values of the specific surface area of the synthesized H-titanates samples are presented in Table 1. Short names of the studied samples given in Table 1 are used throughout the text.

Table 1. Specific surface area of the investigated H-titanates.

\begin{tabular}{cc}
\hline Sample & Specific Surface Area, $\mathbf{~ m}^{\mathbf{2}} \mathbf{g}^{\mathbf{- 1}}$ \\
\hline Nanowires short, NWS & 104 \\
Nanowires long, NWL & 33 \\
Nanotubes short, NTS & 283 \\
Nanotubes long, NTL & 158 \\
Nanosheets, NS & 148 \\
\hline
\end{tabular}


The dependence of the Eu (III) removal from aqueous solution at different $\mathrm{pH} 4$ versus time is shown in Figure 2. The steady state has been reached within 10 min of experiments in all cases. The equilibrium fraction of the sorbed europium (III) is more than $98 \%$.

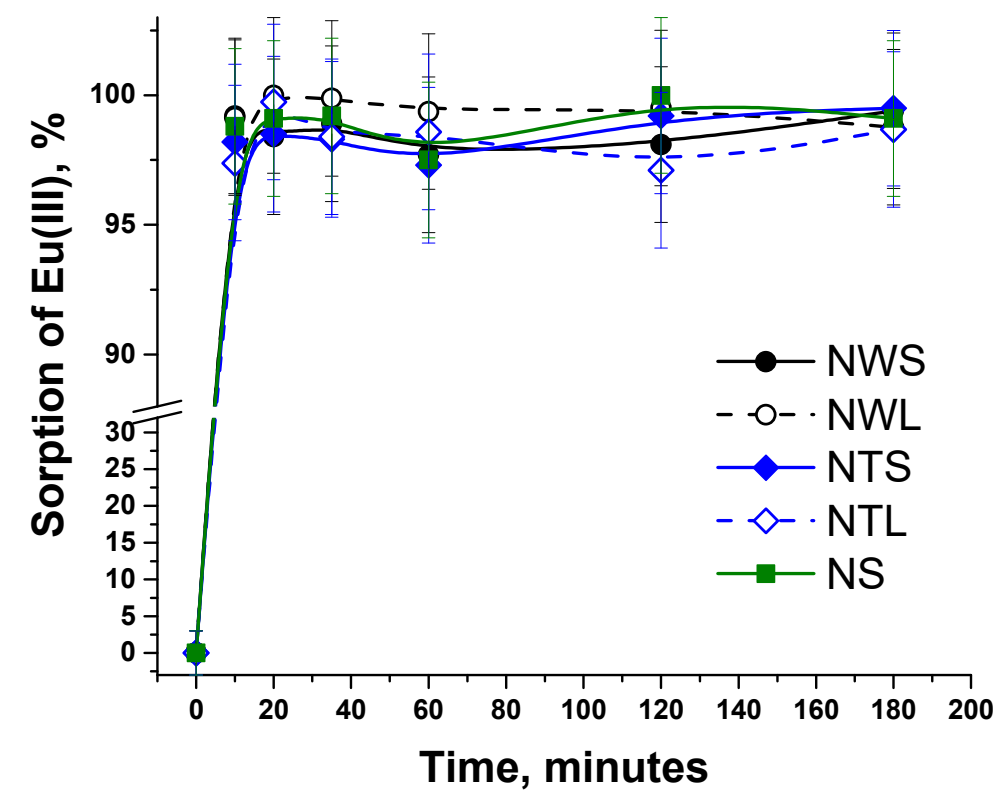

Figure 2. Time dependence of $\mathrm{Eu}$ (III) removal from aqueous solutions at $\mathrm{pH} 4$ by $\mathrm{H}$-titanates of different morphology.

The removal of europium (III) from aqueous solutions at different $\mathrm{pH}$ values by $\mathrm{H}$-titanates of different structures at steady state is shown in Figure 3. The complete recovery of Eu (III) occurs at pH 4 for all investigated $\mathrm{H}$-titanates.

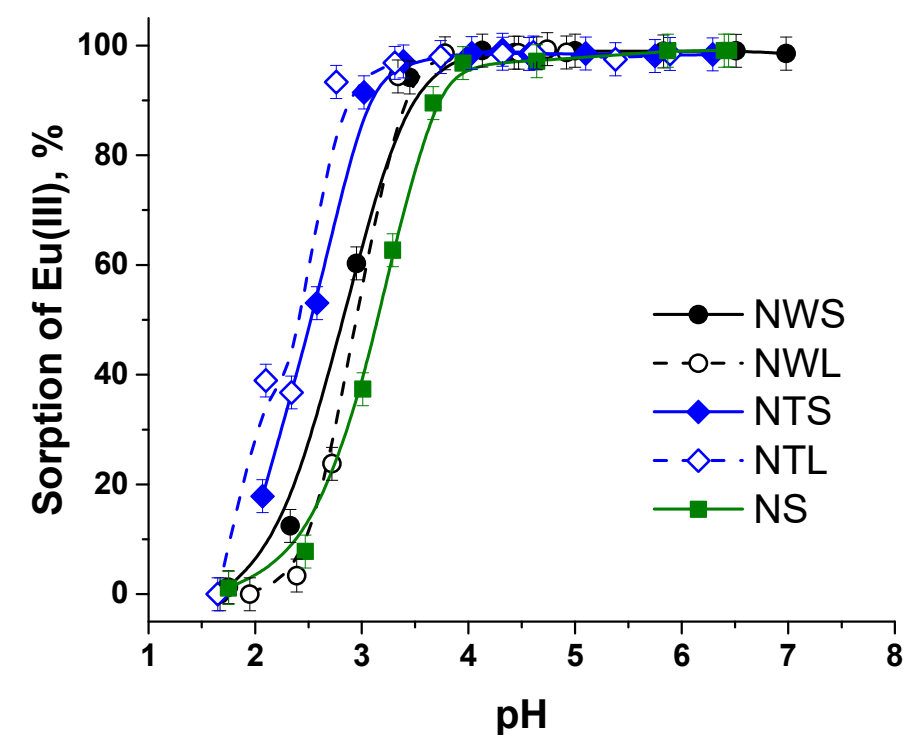

Figure 3. Removal (\%) of europium (III) from aqueous solutions at different $\mathrm{pH}$ values.

Strong sorption of cations can lead to their irreversible fixation. We have performed desorption studies after sorption experiments by shifting $\mathrm{pH}$ values to more acidic. During desorption studies the supernatant solutions were not changed, but only small portions of $\mathrm{HCl}$ solutions were added to shift the $\mathrm{pH}$ values to lower values. The results for all the investigated samples are presented in Figure 4 . The example scheme of $\mathrm{pH}$ shifting (arrows) is presented in Figure $4 \mathrm{a}$ for short nanotubes. 


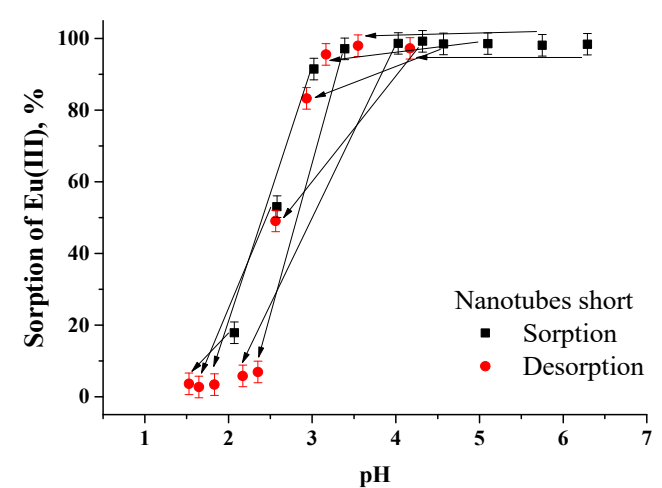

(a)

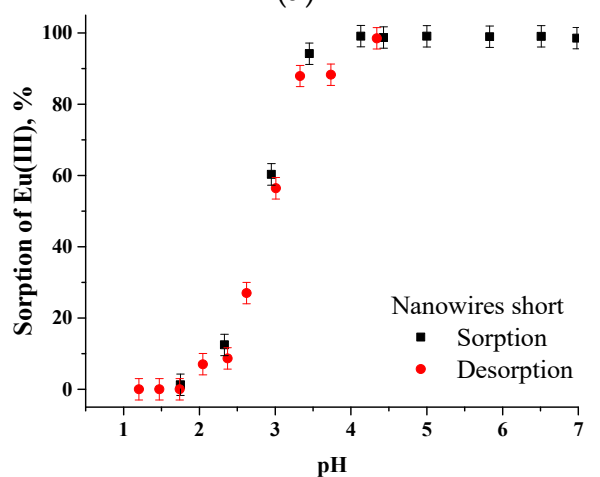

(c)

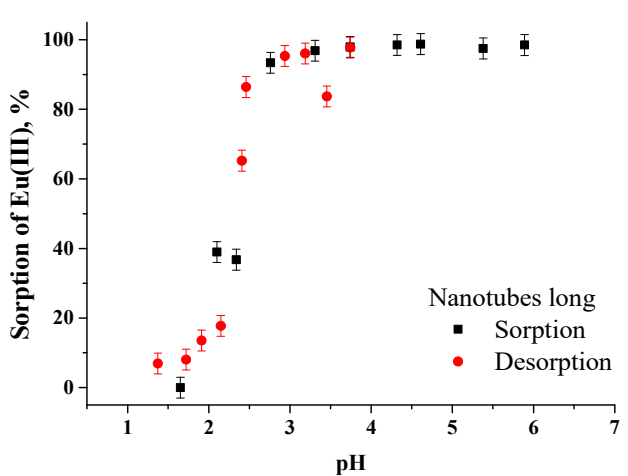

(b)

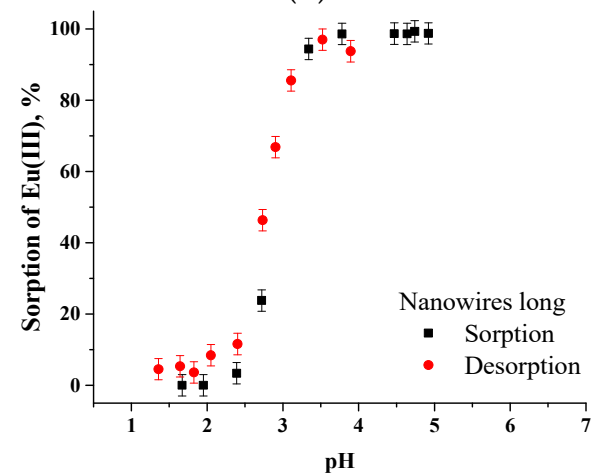

(d)

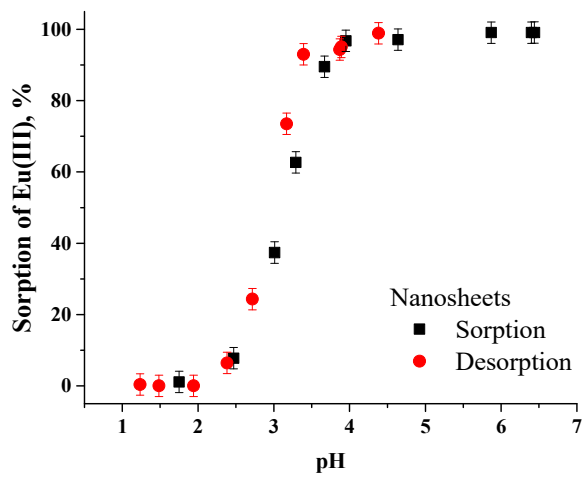

(e)

Figure 4. Results of Eu (III) sorption-desorption experiments for: (a) nanotubes short; (b) nanotubes long; (c) nanowires short; (d) nanowires long; (e) nanosheets.

Investigated H-titanates have different morphology and specific surface areas (see Table 1). Thus, it is useful to compare specific sorption properties of these materials, e.g., distribution coefficient (Kd). We calculated the Kd values with Equation (1):

$$
K d=\frac{\% /(S \cdot m)}{(100-\%) / V}
$$

where $\mathrm{Kd}$-is the distribution coefficient, $\mathrm{mL} \mathrm{m}^{-2} ; \%$ - fraction of a sorbed cation; $\mathrm{V}$ - volume of the sample, $\mathrm{mL} ; \mathrm{S}$ - specific surface area, $\mathrm{m}^{2} \mathrm{~g}^{-1} ; \mathrm{m}$-mass of the sorbent, $\mathrm{g}$.

The resulting values of $\mathrm{Kd}$ are presented in Figure 5. The values of sorbed Eu (III) fraction expressed in percentage units demonstrate almost no difference between different $\mathrm{H}$-titanates at $\mathrm{pH}$ values above 4 (see Figure 2). However, Kd values differ significantly-at least order of magnitude between long nanowire (NWL) and long nanotube (NTL) samples. The reason is the sensitivity of $\mathrm{Kd}$ values to very high (close to $100 \%$ ) or very low (close to $0 \%$ ) sorption percentage. In this range, 
the uncertainty of radioactivity measurements is even bigger than the "(100-\%)" term in Equation (1). Thus, Kd values cannot be correctly used for the investigated system at $\mathrm{pH}>4$.

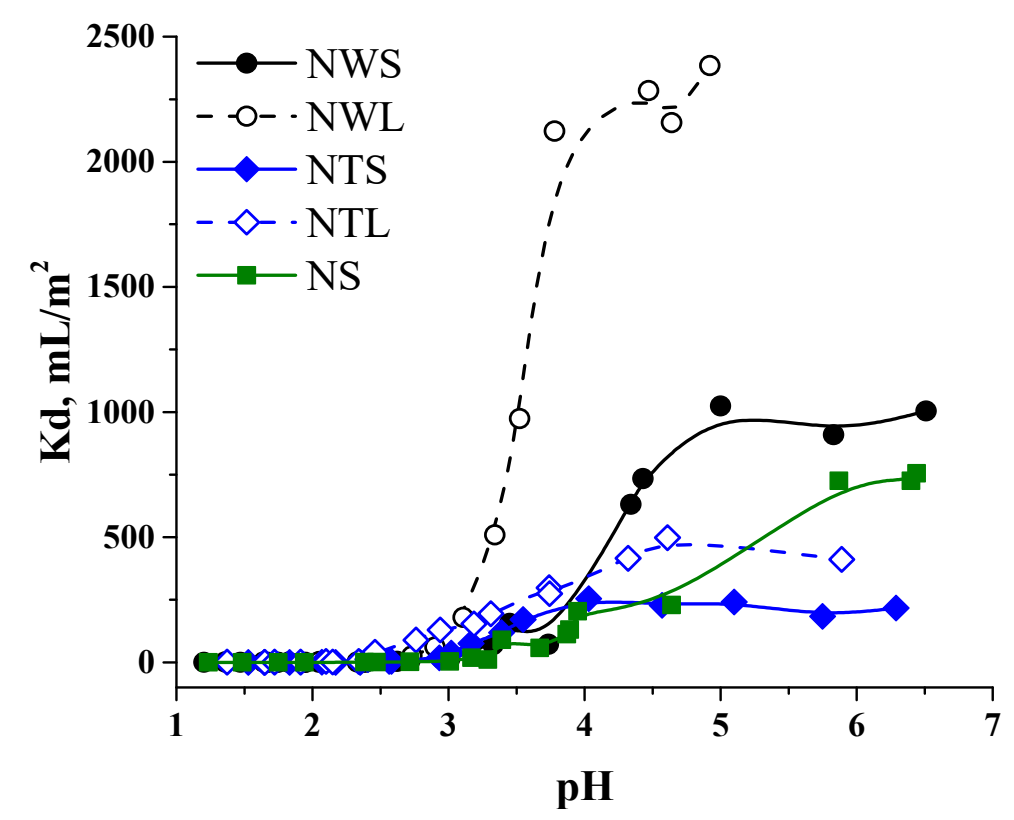

Figure 5. Distribution coefficients of Eu (III) onto H-titanates of different morphology.

\section{Discussion}

The obtained materials demonstrate different morphology, specific surface area, and sorption capacities towards $\mathrm{Eu}$ (III) ions. It must be noted that X-ray diffraction analysis demonstrates that all the materials are mixtures of different $\mathrm{H}$-titanates and admixtures of titanium oxides.

The effect of $\mathrm{pH}$ on $\mathrm{Eu}$ (III) sorption percentage is shown in Figures 3 and 4. A pronounced rise of $\mathrm{Eu}$ (III) sorption from 0 to $100 \%$ is observed within $\mathrm{pH}$ values $2-4$. The typical $\mathrm{pH}$ range of the trivalent metal cations sorption edge on different oxide surfaces is within 2-6 [3,30-32]. Thus, $\mathrm{H}$-titanates demonstrate very strong binding with $\mathrm{Eu}$ (III).

The high values of the trivalent f-elements (lanthanides and actinides) removal (Figures 2 and 3) can be usually explained by their high tendency to sorb onto different mineral surfaces and by formation of strong inner-sphere complexes with different surface hydroxyl groups (e.g., $\equiv$ Ti-OH) $[3,33]$. The spectroscopic studies and quantum-chemical calculations are ongoing to determine the sorbed complexes of $\mathrm{Eu}$ (III) onto H-titanates.

The investigated samples of H-titanates demonstrate total reversibility of Eu sorption (Figure 4). This is again typical for the sorption by formation of inner-sphere complexes with surface hydroxyl groups. This is similar to the commonly known hydrolysis reactions; hydrolysis species (like complexes with surface groups) form with $\mathrm{pH}$ increasing, but can be decomposed by increasing the acidity, i.e., $\mathrm{pH}$ decreasing. Europium is considered as a chemical analogue of trivalent actinides, which was confirmed in several sorption studies with different materials [34-36]. Thus, H-titanates can be applied for reversible extraction of trivalent lanthanides and actinides. For example, trivalent f-elements can be sorbed at $\mathrm{pH} 7-8$ (typical for many natural waters) and then be removed in acidic conditions $(\mathrm{pH}<3$ ) to recycle the sorbent. Additionally, sorbents with the adsorbed trivalent f-elements can be removed from the solution by centrifugation or filtration. After that, they can be annealed at temperatures above $300{ }^{\circ} \mathrm{C}$ to form very stable $\mathrm{TiO}_{2}$ phases in which lanthanides or actinides can be encapsulated. Thus, the investigated $\mathrm{H}$-titanates can serve as a precursor of the stable matrix for the immobilization of trivalent actinides.

Fitting of the sorption isotherms with the Langmuir equation gives the following values for the maximum sorption capacity of the investigated samples: nanosheets $0.62 \mu \mathrm{mol} \mathrm{m}{ }^{-2}\left(91.8 \mu \mathrm{mol} \mathrm{g}^{-1}\right.$, 
$\left.14.0 \mathrm{mg} \mathrm{g}^{-1}\right)$, nanowires short $0.45 \mu \mathrm{mol} \mathrm{m}^{-2}\left(46.8 \mu \mathrm{mol} \mathrm{g}^{-1}, 7.1 \mathrm{mg} \mathrm{g}^{-1}\right)$, nanowires long $0.39 \mu \mathrm{mol}$ $\mathrm{m}^{-2}\left(12.9 \mu \mathrm{mol} \mathrm{g}^{-1}, 2.0 \mathrm{mg} \mathrm{g}^{-1}\right)$, nanotubes short $0.53 \mu \mathrm{mol} \mathrm{m}^{-2}\left(150.0 \mu \mathrm{mol} \mathrm{g}^{-1}, 22.8 \mathrm{mg} \mathrm{g}^{-1}\right)$, nanotubes long $0.41 \mu \mathrm{mol} \mathrm{m}^{-2}\left(64.8 \mu \mathrm{mol} \mathrm{g}-1,9.8 \mathrm{mg} \mathrm{g}^{-1}\right)$. The sorption capacity values of H-titanates of different morphology relative to the surface area are very close. That means affinity to Eu (III) and number of sorption sites per surface area are similar for the investigated samples. However, more precise studies are required to understand the difference. Due to the significant difference in specific surface area, the mass sorption capacity values (per g) differ from sample to sample.

Table 2 represents the comparison of Eu (III) sorption capacity of the investigated samples with some other materials. Different authors reported sorption capacity either as $\mathrm{mg} \mathrm{g}^{-1}$ or as $\mathrm{mol} \mathrm{g}^{-1}$. In Table 2 we have recalculated respective values by using the atomic mass of stable europium, equal to 151.964 according to the latest version of IUPAC Technical Report [37], and rounded the values to the first decimal place (the original numbers are presented as published). As it can be seen from Table 2, H-titanates are not superior materials for Eu sorption. However, fast and reversible sorption of different cations [21-26] and possibility for further transformation to a very stable $\mathrm{TiO}_{2}$ make this materials perspective for applications in purification of water solutions.

Table 2. Eu (III) sorption capacity of different materials [2,14,38-59].

\begin{tabular}{|c|c|c|c|c|}
\hline \multirow{2}{*}{ Material } & \multirow{2}{*}{$\mathrm{pH}$} & \multicolumn{2}{|c|}{ Sorption Capacity } & \multirow{2}{*}{ Reference } \\
\hline & & $\mathrm{mg} \mathrm{g}^{-1}$ & $\mu \mathrm{mol} \mathrm{g}{ }^{-1}$ & \\
\hline H-Titanates nanowires short & 4.1 & 7.1 & 46.8 & This study \\
\hline H-Titanates nanowires long & 4.1 & 2.0 & 12.9 & This study \\
\hline H-Titanates nanotubes short & 4.2 & 22.8 & 150.0 & This study \\
\hline H-Titanates nanotubes long & 4.2 & 9.8 & 64.8 & This study \\
\hline H-Titanates nanosheets & 4.2 & 14.0 & 91.8 & This study \\
\hline Multi-walled carbon nanotubes (MWCNT) & 4.3 & 1.4 & 9.24 & [38] \\
\hline $\mathrm{TiO}_{2}$ & 4.5 & 1.5 & 9.91 & [39] \\
\hline ZSM-5 zeolite & $\begin{array}{l}3.62 \\
4.85\end{array}$ & $\begin{array}{l}2.4 \\
3.3\end{array}$ & $\begin{array}{l}15.9 \\
21.6\end{array}$ & [40] \\
\hline Humic acid-MWCNT hybrid & 4.3 & 2.6 & 17.4 & [38] \\
\hline $\begin{array}{l}\text { 4-(2- Pyridylazo) resorcinol loaded polyurethane } \\
\text { foam (PAR-PUF) }\end{array}$ & 7.0 & 3.0 & 19.5 & [41] \\
\hline $\mathrm{Al}_{2} \mathrm{O}_{3} /$ expanded graphite & $\begin{array}{l}4.0 \\
6.0\end{array}$ & $\begin{array}{l}4.74 \\
5.14\end{array}$ & $\begin{array}{l}31.2 \\
33.8\end{array}$ & [42] \\
\hline $\begin{array}{l}\text { SBA-15 mesoporous silicas functionalized with } \\
\text { N-propyl salicylaldimine (SBA/SA) }\end{array}$ & 4.0 & 5.1 & 33.6 & [43] \\
\hline Magnetite nanoparticles & 2.5 & 5.75 & 37.8 & [44] \\
\hline Cellulose acetate (CA) membrane & 5.0 & 9.35 & 61.5 & [45] \\
\hline $\mathrm{Fe}_{3} \mathrm{O}_{4} @$ Humic acid magnetic nanoparticles & 5.0 & 10.6 & 69.5 & [46] \\
\hline $\begin{array}{l}\text { 2-thenoyltrifluoroacetone loaded polyurethane } \\
\text { foam (HTTA-PUF) }\end{array}$ & 3.5 & 12.5 & 82.0 & [47] \\
\hline $\begin{array}{l}\text { SBA-15 mesoporous silicas functionalized with } \\
\text { ethylenediaminepropylesalicylaldimine } \\
\text { (SBA/EnSA) }\end{array}$ & 4.0 & 15.6 & 102.7 & [43] \\
\hline 8-Hydroxyquinoline (HQ)/benzene/silica gel & 4.2 & 18.52 & 121.9 & [48] \\
\hline Titanate nanotubes & 4.5 & 18.8 & 124.0 & [49] \\
\hline
\end{tabular}


Table 2. Cont.

\begin{tabular}{|c|c|c|c|c|}
\hline \multirow{2}{*}{ Material } & \multirow{2}{*}{$\mathrm{pH}$} & \multicolumn{2}{|c|}{ Sorption Capacity } & \multirow{2}{*}{ Reference } \\
\hline & & $\mathrm{mg} \mathrm{g}^{-1}$ & $\mu \mathrm{mol} \mathrm{g}{ }^{-1}$ & \\
\hline CA-AAm (Acrylamide) membrane & 5.0 & 19.08 & 125.6 & [45] \\
\hline \multirow{2}{*}{ Activated carbon } & 4.5 & 20.12 & 132.4 & [50] \\
\hline & 5.0 & 46.5 & 306.0 & [51] \\
\hline Sepiolite & 6.0 & 22.85 & 150.4 & [52] \\
\hline CA-PEG (Polyethylene glycol) membrane & 5.0 & 27.40 & 180.3 & [45] \\
\hline Magnetic $\mathrm{Fe}_{3} \mathrm{O}_{4} /$ sepiolite composite & 5.0 & 30.85 & 203.0 & [53] \\
\hline $\mathrm{CMPO}$ on $\mathrm{SiO}_{2}$ & $3 \mathrm{M} \mathrm{HNO}_{3}$ & 31.3 & 206.0 & [14] \\
\hline$\alpha-\mathrm{Ti}\left(\mathrm{HPO}_{4}\right) \cdot 2 \mathrm{H}_{2} \mathrm{O}$ & 6.0 & 40.6 & 267.2 & [54] \\
\hline Molecular sieve (Al-MCM-41) & 5.0 & 43.2 & 284.0 & [55] \\
\hline Carbonaceous nanofibers & 4.5 & 62.6 & 411.9 & [56] \\
\hline Magnetic graphene oxide & 4.5 & 70.15 & 461.6 & [57] \\
\hline Layered Metal Sulfide $\left(\mathrm{KInSn}_{2} \mathrm{~S}_{6}\right)$ & 2.0 & 86.58 & 569.7 & [58] \\
\hline \multirow{4}{*}{ Graphene oxide } & 4.5 & 89.654 & 590.0 & [57] \\
\hline & 5.0 & 115.5 & 760.0 & {$[2]$} \\
\hline & 4.5 & 161.29 & 1061.4 & [50] \\
\hline & 6.0 & 175.44 & 1154.5 & [50] \\
\hline $\begin{array}{l}\mathrm{Mg}-\mathrm{Al} \text { layered double hydroxide intercalated with } \\
\text { nitrate anions }\left(\mathrm{LDH}-\mathrm{NO}_{3}\right)\end{array}$ & 4.25 & 119.56 & 786.8 & [59] \\
\hline $\begin{array}{l}\text { LDH modified with sodium lauryl sulfate } \\
\text { (LDH-NaLS) }\end{array}$ & 4.25 & 156.45 & 1029.5 & [59] \\
\hline
\end{tabular}

\section{Conclusions}

Investigated H-titanates of different nanostructures demonstrate fast and efficient sorption of trivalent lanthanides from aqueous solutions. The sorption of $\mathrm{Eu}$ (III) is strongly dependent on $\mathrm{pH}$ values, but almost independent on structure of $\mathrm{H}$-titanates. These results, along with low solubility of $\mathrm{H}$-titanates and previous data reported in literature, show that these materials have a high potential for the decontamination of polluted wastewater and groundwater.

Author Contributions: Conceptualization, V.G.P. and Z.C.; methodology, V.G.P. and Z.C.; investigation, A.Y.R., V.O.D. and Y.T.; resources, S.N.K. and Z.C.; writing-original draft preparation, V.G.P.; writing-review and editing, S.N.K.; visualization, V.G.P.; supervision, V.G.P.; project administration, S.N.K.; funding acquisition, S.N.K. and Z.C.

Funding: The Eu (III) sorption studies were supported by Russian Science Foundation (project 14-13-01279). The synthesis and characterization of the H-titanate samples were supported by Singapore National Research Foundation (MEWR 651/06/160).

Conflicts of Interest: The authors declare no conflict of interest. The funders had no role in the design of the study; in the collection, analyses, or interpretation of data; in the writing of the manuscript, or in the decision to publish the results.

\section{References}

1. Myasoedov, B.F.; Kalmykov, S.N. Nuclear power industry and the environment. Mendeleev Commun. 2015, 25, 319-328. [CrossRef]

2. Romanchuk, A.Y.; Slesarev, A.S.; Kalmykov, S.N.; Kosynkin, D.V.; Tour, J.M. Graphene Oxide for Effective Radionuclide Removal. Phys. Chem. Chem. Phys. 2013, 15, 2321-2327. [CrossRef] [PubMed]

3. Gracheva, N.N.; Romanchuk, A.Y.; Smirnov, E.A.; Meledina, M.A.; Garshev, A.V.; Shirshin, E.A.; Fadeev, V.V.; Kalmykov, S.N. Am(III) sorption onto $\mathrm{TiO}_{2}$ samples with different crystallinity and varying pore size distributions. Appl. Geochem. 2014, 42, 69-76. [CrossRef] 
4. Noronha, D.M.; Pius, I.C.; Mukerjee, S.K. Preparation of thorium oxalate-silica sorbent and its application for the sorption of americium from aqueous solutions. J. Radioanal. Nuclear Chem. 2011, 289, 75-81. [CrossRef]

5. Lujanienè, G.; Meleshevych, S.; Kanibolotskyy, V.; Šapolaitè, J.; Strelko, V.; Remeikis, V.; Oleksienko, O.; Ribokaite, K.; Ščiglo, T. Application of inorganic sorbents for removal of Cs, Sr, Pu and Am from contaminated solutions. J. Radioanal. Nuclear Chem. 2009, 282, 787-791. [CrossRef]

6. Chen, C.L.; Wang, X.K.; Nagatsu, M. Europium Adsorption on Multiwall Carbon Nanotube/Iron Oxide Magnetic Composite in the Presence of Polyacrylic Acid. Environ. Sci. Technol. 2009, 43, 2362-2367. [CrossRef] [PubMed]

7. Sharma, P.; Singh, G.; Tomar, R. Synthesis and characterization of an analogue of heulandite: Sorption applications for thorium(IV), europium(III), samarium(II) and iron(III) recovery from aqueous waste. J. Colloid Interface Sci. 2009, 332, 298-308. [CrossRef]

8. Banerjee, C.; Dudwadkar, N.; Tripathi, S.C.; Gandhi, P.M.; Grover, V.; Kaushik, C.P.; Tyagi, A.K. Nano-cerium vanadate: A novel inorganic ion exchanger for removal of americium and uranium from simulated aqueous nuclear waste. J. Hazard. Mater. 2014, 280, 63-70. [CrossRef]

9. Gracheva, N.N.; Romanchuk, A.Y.; Bryukhanova, K.I.; Gavrichev, K.S.; Kalmykov, S.N. Sorption of Am(III) onto orthophosphates of the rare-earth elements with different crystal structures. Mendeleev Commun. 2017, 27, 188-191. [CrossRef]

10. Potts, M.E.; Churchwell, D.R. Removal of Radionuclides in Wastewaters Utilizing Potassium Ferrate(VI). Water Environ. Res. 1994, 66, 107-109. [CrossRef]

11. Petrov, V.; Perfiliev, Y.; Dedushenko, S.; Kuchinskaya, T.; Kalmykov, S. Radionuclide removal from aqueous solutions using potassium ferrate(VI). J. Radioanal. Nuclear Chem. 2016, 310, 347-352. [CrossRef]

12. Mann, N.R.; Todd, T.A.; Tranter, T.J.; Šebesta, F. Development of novel composite sorbents for the removal of actinides from environmental and analytical solutions. J. Radioanal. Nuclear Chem. 2002, 254, 41-45. [CrossRef]

13. Myasoedova, G.V.; Molochnikova, N.P.; Kulyako, Y.M.; Myasoedov, B.F. Filled Fibrous Sorbents Modified with Transition Metal Ferro- and Ferricyanides for Recovery of Americium and Rare-Earth Metals. J. Radioanal. Nuclear Chem. 2003, 45, 61-62.

14. Pietrelli, L.; Salluzzo, A.; Troiani, F. Sorption of europium and actinides by means of octyl(phenyl)-N,N-diisobutyl carbamoylmethyl phosphine oxide (CMPO) loaded on silica. J. Radioanal. Nuclear Chem. 1990, 141, 107-115. [CrossRef]

15. Lu, S.; Xu, J.; Zhang, C.; Niu, Z. Adsorption and desorption of radionuclide europium(III) on multiwalled carbon nanotubes studied by batch techniques. J. Radioanal. Nuclear Chem. 2011, 287, 893-898. [CrossRef]

16. Barr, M.E.; Jarvinen, G.D.; Stark, P.C.; Chamberlin, R.M.; Bartsch, R.A.; Zhang, Z.Y.; Zhao, W. Americium separations from high-salt solutions using anion exchange. Sep. Sci. Technol. 2001, 36, $2609-2622$. [CrossRef]

17. La Rosa, J.J.; Burnett, W.; Lee, S.H.; Levy, I.; Gastaud, J.; Povinec, P.P. Separation of actinides, cesium and strontium from marine samples using extraction chromatography and sorbents. J. Radioanal. Nuclear Chem. 2001, 248, 765-770. [CrossRef]

18. Sengupta, A.; Adya, V.C.; Mohapatra, P.K.; Godbole, S.V.; Manchanda, V.K. Separation and purification of americium from analytical waste solutions. J. Radioanal. Nuclear Chem. 2010, 283, 777-783. [CrossRef]

19. Lim, Y.W.L.; Tang, Y.; Cheng, Y.H.; Chen, Z. Morphology, crystal structure and adsorption performance of hydrothermally synthesized titania and titanate nanostructures. Nanoscale 2010, 2, 2751-2757. [CrossRef]

20. Zhang, Y.Y.; Jiang, Z.L.; Huang, J.Y.; Lim, L.Y.; Li, W.L.; Deng, J.Y.; Gong, D.G.; Tang, Y.X.; Lai, Y.K.; Chen, Z. Titanate and Titania Nanostructured Materials for Environmental and Energy Applications: A Review. RSC Adv. 2015, 5, 79479-79510. [CrossRef]

21. Tang, Y.; Gong, D.; Lai, Y.; Shen, Y.; Zhang, Y.; Huang, Y.; Tao, J.; Lin, C.; Dong, Z.; Chen, Z. Hierarchical layered titanate microspherulite: Formation by electrochemical spark discharge spallation and application in aqueous pollutant treatment. J. Mater. Chem. 2001, 20, 10169-10178. [CrossRef]

22. Yang, D.; Zheng, Z.; Liu, H.; Zhu, H.; Ke, X.; Xu, Y.; Wu, D.; Sun, Y. Layered Titanate Nanofibers as Efficient Adsorbents for Removal of Toxic Radioactive and Heavy Metal Ions from Water. J. Phys. Chem. C 2008, 112, 16275-16280. [CrossRef]

23. Ma, R.; Sasaki, T.; Bando, Y. Alkali metal cation intercalation properties of titanate nanotubes. Chem. Commun. 2005, 7, 948-950. [CrossRef] [PubMed] 
24. Liu, J.; Luo, M.; Yuan, Z.; Ping, A. Synthesis, characterization, and application of titanate nanotubes for Th(IV) adsorption. J. Radioanal. Nuclear Chem. 2013, 298, 1427-1434. [CrossRef]

25. Sheng, G.; Hu, J.; Alsaedi, A.; Shammakh, W.; Monaquel, S.; Ye, F.; Li, H.; Huang, Y.; Alshomrani, A.S.; Jayat, T.; et al. Interaction of uranium(VI) with titanate nanotubes by macroscopic and spectroscopic investigation. J. Mol. Liq. 2015, 212, 563-568. [CrossRef]

26. Liu, W.; Zhao, X.; Wang, T.; Zhao, D.; Ni, J. Adsorption of U(VI) by multilayer titanate nanotubes: Effects of inorganic cations, carbonate and natural organic matter. Chem. Eng. J. 2016, 286, 427-435. [CrossRef]

27. Lai, Y.K.; Tang, Y.X.; Gong, J.J.; Gong, D.G.; Chi, L.F.; Lin, C.J.; Chen, Z. Transparent superhydrophobic/superhydrophilic $\mathrm{TiO}_{2}$-based coatings for self-cleaning and anti-fogging. J. Mater. Chem. 2012, 22, 7420-7426. [CrossRef]

28. Tang, Y.X.; Zhang, Y.Y.; Deng, J.Y.; Qi, D.P.; Leow, W.R.; Wei, J.Q.; Yin, S.Y.; Dong, Z.L.; Yazami, R.; Chen, Z; et al. Unravelling the Correlation between the Aspect Ratio of Nanotubular Structures and Their Electrochemical Performance to Achieve High-Rate and Long-Life Lithium-Ion Batteries. Angew. Chem. Intern. Ed. 2014, 53, 13488-13492. [CrossRef]

29. Brunauer, S.; Emmett, P.H.; Teller, E. Adsorption of Gases in Multimolecular Layers. J. Am. Chem. Soc. 1938, 60, 309-319. [CrossRef]

30. Romanchuk, A.Y.; Kalmykov, S.N. Actinides sorption onto hematite: Experimental data, surface complexation modeling and linear free energy relationship. Radiochim. Acta 2014, 102, 303-310. [CrossRef]

31. Wang, X.; Xu, D.; Chen, L.; Tan, X.; Zhou, X.; Ren, A.; Chen, C. Sorption and complexation of Eu(III) on alumina: Effects of $\mathrm{pH}$, ionic strength, humic acid and chelating resin on kinetic dissociation study. Appl. Radiat. Isot. 2006, 64, 414-421. [CrossRef] [PubMed]

32. Estes, S.L.; Arai, Y.; Becker, U.; Fernando, S.; Yuan, K.; Ewing, R.C.; Zhang, J.; Shibata, T.; Powell, B.A. A self-consistent model describing the thermodynamics of Eu(III) adsorption onto hematite. Geochim. Cosmochim. Acta 2013, 122, 430-447. [CrossRef]

33. Guo, Z.; Wang, S.; Shi, K.; Wu, W. Experimental and modeling studies of Eu(III) sorption on $\mathrm{TiO}_{2}$. Radiochim. Acta 2009, 97, 283-289. [CrossRef]

34. Rabung, T.; Pierret, M.C.; Bauer, A.; Geckeis, H.; Bradbury, M.H.; Baeyens, B. Sorption of Eu(III)/Cm(III) on Ca-montmorillonite and Na-illite. Part 1: Batch sorption and time-resolved laser fluorescence spectroscopy experiments. Geochim. Cosmochim. Acta 2005, 69, 5393-5402. [CrossRef]

35. Rabung, T.; Stumpf, T.; Geckeis, H.; Klenze, R.; Kim, J.I. Sorption of Am(III) and Eu(III) onto $\gamma$-alumina: Experiment and modeling. Radiochim. Acta 2000, 88, 711-716. [CrossRef]

36. Kupcik, T.; Rabung, T.; Lützenkirchen, J.; Finck, N.; Geckeis, H.; Fanghänel, T. Macroscopic and spectroscopic investigations on $\mathrm{Eu}(\mathrm{III})$ and $\mathrm{Cm}(\mathrm{III})$ sorption onto bayerite $\left(\beta-\mathrm{Al}(\mathrm{OH})_{3}\right)$ and corundum $\left(\alpha-\mathrm{Al}_{2} \mathrm{O}_{3}\right)$. J. Colloid Interface Sci. 2016, 461, 215-224. [CrossRef]

37. Meija, J.; Coplen, T.B.; Berglund, M.; Brand, W.A.; De Bièvre, P.; Gröning, M.; Holden, N.E.; Irrgeher, J.; Loss, R.D.; Walczyk, T.; et al. Atomic weights of the elements 2013 (IUPAC Technical Report). Pure Appl. Chem. 2016, 88, 265-291. [CrossRef]

38. Fan, Q.H.; Shao, D.D.; Hu, J.; Chen, C.L.; Wu, W.S.; Wang, X.K. Adsorption of humic acid and Eu(III) to multi-walled carbon nanotubes: Effect of $\mathrm{pH}$, ionic strength and counterion effect. Radiochim. Acta 2009, 97, 141-148. [CrossRef]

39. Tan, X.; Fang, M.; Li, J.; Lu, Y.; Wang, X. Adsorption of Eu(III) onto $\mathrm{TiO}_{2}$ : Effect of $\mathrm{pH}$, concentration, ionic strength and soil fulvic acid. J. Hazard. Mater. 2009, 168, 458-465. [CrossRef]

40. Shao, D.D.; Fan, Q.H.; Li, J.X.; Niu, Z.W.; Wu, W.S.; Chen, Y.X.; Wang, X.K. Removal of Eu(III) from aqueous solution using ZSM-5 zeolite. Microporous Mesoporous Mater. 2009, 123, 1-9. [CrossRef]

41. Saeed, M.M.; Ahmed, M.; Chaudary, M.H.; Gaffar, A. Kinetics, Thermodynamics, and Sorption Profile of Eu(III) and Tm(III) on 4-(2-Pyridylazo) Resorcinol (PAR) Imbedded Polyurethane Foam. Solvent Extr. Ion Exch. 2003, 21, 881-898. [CrossRef]

42. Sun, Y.; Chen, C.; Tan, X.; Shao, D.; Li, J.; Zhao, G.; Yang, S.; Wang, Q.; Wang, X. Enhanced adsorption of $\mathrm{Eu}(\mathrm{III})$ on mesoporous $\mathrm{Al}_{2} \mathrm{O}_{3}$ /expanded graphite composites investigated by macroscopic and microscopic techniques. Dalton Trans. 2012, 41, 13388-13394. [CrossRef] [PubMed]

43. Dolatyari, L.; Yaftian, M.R.; Rostamnia, S. Adsorption characteristics of Eu(III) and Th(IV) ions onto modified mesoporous silica SBA-15 materials. J. Taiwan Inst. Chem. Eng. 2016, 60, 174-184. [CrossRef] 
44. Li, M.; Sun, Y.; Liu, H.; Chen, T.; Hayat, T.; Alharbi, N.S.; Chen, C. Spectroscopic and Modeling Investigation of $\mathrm{Eu}(\mathrm{III}) / \mathrm{U}(\mathrm{VI})$ Sorption on Nanomagnetite from Aqueous Solutions. ACS Sustain. Chem. Eng. 2017, 5, 5493-5502. [CrossRef]

45. Zaki, A.A.; El-Zakla, T.; Abed El Geleel, M. Modeling kinetics and thermodynamics of $\mathrm{Cs}^{+}$and $\mathrm{Eu}^{3+} \mathrm{removal}^{3}$ from waste solutions using modified cellulose acetate membranes. J. Membr. Sci. 2012, 401-402, 1-12. [CrossRef]

46. Yang, S.; Zong, P.; Ren, X.; Wang, Q.; Wang, X. Rapid and highly efficient preconcentration of Eu(III) by core-shell structured $\mathrm{Fe}_{3} \mathrm{O}_{4} @$ humic acid magnetic nanoparticles. ACS Appl. Mater. Interfaces 2012, 4, 6891-6900. [CrossRef]

47. Saeed, M.M. Adsorption profile and thermodynamic parameters of the preconcentration of Eu(III) on 2-thenoyltrifluoroacetone loaded polyurethane (PUR) foam. J. Radioanal. Nuclear Chem. 2003, 256, 73-80. [CrossRef]

48. El-Shazly, E.A.A.; Sheha, R.R.; Someda, H.H. Factors affecting the sorption of Eu(III) on modified silica gel. J. Radioanal. Nuclear Chem. 2006, 268, 255-260. [CrossRef]

49. Sheng, G.; Dong, H.; Shen, R.; Li, Y. Microscopic insights into the temperature-dependent adsorption of $\mathrm{Eu}(\mathrm{III})$ onto titanate nanotubes studied by FTIR, XPS, XAFS and batch technique. Chem. Eng. J. 2013, 217, 486-494. [CrossRef]

50. Sun, Y.; Wang, Q.; Chen, C.; Tan, X.; Wang, X. Interaction between Eu(III) and graphene oxide nanosheets investigated by batch and extended $\mathrm{X}$-ray absorption fine structure spectroscopy and by modeling techniques. Environ. Sci. Technol. 2012, 46, 6020-6027. [CrossRef]

51. Gad, H.M.H.; Awwad, N.S. Factors Affecting on the Sorption/Desorption of Eu(III) using Activated Carbon. Sep. Sci. Technol. 2007, 42, 3657-3680. [CrossRef]

52. Sun, Y.; Li, J.; Wang, X. The retention of uranium and europium onto sepiolite investigated by macroscopic, spectroscopic and modeling techniques. Geochim. Cosmochim. Acta 2014, 140, 621-643. [CrossRef]

53. Yu, S.; Liu, X.; Xu, G.; Qiu, Y.; Cheng, L. Magnetic $\mathrm{Fe}_{3} \mathrm{O}_{4}$ /sepiolite composite synthesized by chemical co-precipitation method for efficient removal of Eu(III). Desalin. Water Treat. 2016, 57, 16943-16954. [CrossRef]

54. Ortíz-Oliveros, H.B.; Flores-Espinosa, R.M.; Ordoñez-Regil, E.; Fernández-Valverde, S.M. Synthesis of $\alpha-\mathrm{Ti}\left(\mathrm{HPO}_{4}\right) \cdot 2 \mathrm{H}_{2} \mathrm{O}$ and sorption of Eu(III). Chem. Eng. J. 2014, 236, 398-405. [CrossRef]

55. Zuo, L.; Yu, S.; Zhou, H.; Jiang, J.; Tian, X. Adsorption of Eu(III) from aqueous solution using mesoporous molecular sieve. J. Radioanal. Nuclear Chem. 2011, 288, 579-586. [CrossRef]

56. Jin, Z.; Liu, X.; Duan, S.; Yu, X.; Huang, Y.; Hayat, T.; Li, J. The adsorption of Eu(III) on carbonaceous nanofibers: Batch experiments and modeling study. J. Mol. Liq. 2016, 222, 456-462. [CrossRef]

57. Li, D.; Zhang, B.; Xuan, F. The sorption of Eu(III) from aqueous solutions by magnetic graphene oxides: A combined experimental and modeling studies. J. Mol. Liq. 2015, 211, 203-209. [CrossRef]

58. Xiao, C.; Hassanzadeh Fard, Z.; Sarma, D.; Song, T.B.; Xu, C.; Kanatzidis, M.G. Highly Efficient Separation of Trivalent Minor Actinides by a Layered Metal Sulfide $\left(\mathrm{KInSn}_{2} \mathrm{~S}_{6}\right)$ from Acidic Radioactive Waste. J. Am. Chem. Soc. 2017, 139, 16494-16497. [CrossRef] [PubMed]

59. Mahmoud, M.R.; Someda, H.H. Mg-Al layered double hydroxide intercalated with sodium lauryl sulfate as a sorbent for ${ }^{152+154} \mathrm{Eu}$ from aqueous solutions. J. Radioanal. Nuclear Chem. 2012, 292, 1391-1400. [CrossRef]

(C) 2019 by the authors. Licensee MDPI, Basel, Switzerland. This article is an open access article distributed under the terms and conditions of the Creative Commons Attribution (CC BY) license (http://creativecommons.org/licenses/by/4.0/). 